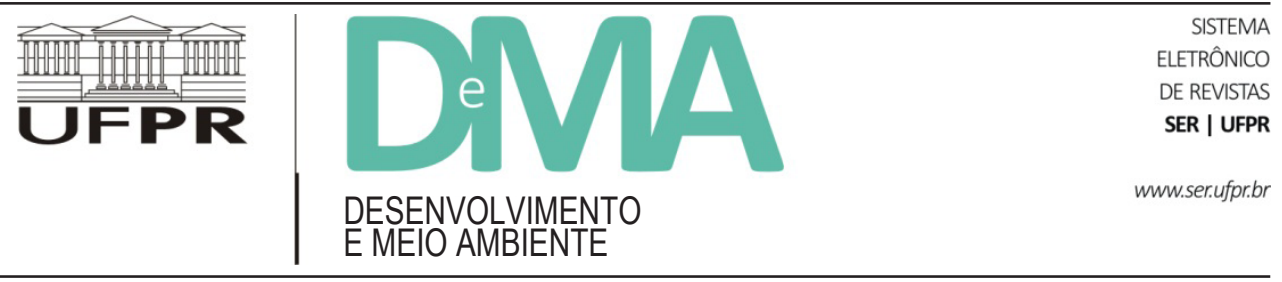

\title{
Are National Parks Inherently Unequal? The 2006 French Park Reform and its Initial Implementation in Mainland France
}

\section{São os Parques Nacionais inerentemente desiguais? A reforma de 2006 dos Parques Franceses e sua implementação inicial na França continental}

\author{
Valérie DELDRÈVE ${ }^{*}$, Cécilia CLAEYS $^{2}$ \\ ${ }^{1}$ Institut national de recherche en sciences et technologies pour l'environnement et l'agriculture (IRSTEA), France. \\ ${ }^{2}$ Laboratoire Population Environnement Développement (LPED), Aix-Marseille Université, France. \\ *E-mail of contact: valerie.deldreve@irstea.fr
}

Article received in December 11, 2015, final version accepted in July 4, 2016.

ABSTRACT: In France, like in other parts of the world, environmental-protection policies appear to have taken note of local resistance driven by the eviction of populations and restrictions on their use of certain areas. The amendment to the law on French national parks (2006 reform) as such recognized that local populations can help to protect natural environments, as well as their right to participate in defining the charter (or spatial plan) of new parks. This article analyses the creation and local acceptance of the Calanques National Park, a peri-urban park and the first of a new generation of parks in mainland France. Our approach is based on the analytical framework of environmental effort. Using a qualitative corpus of semi-structured interviews and direct observation, we explore three analytical axes. We begin by analyzing the consultation process conducted during the creation of the park. This points up inequalities in access to the public sphere and underscores that only a few, wellendowed user-organizations truly helped define the "good use" of the Calanques that became a reference in the park's charter. Then we examine how such unequal user participation impacted the wording used in the charter and the distribution of environmental effort demanded of different users. Lastly, the first two observations lead us to question the acceptability of the effort required and its division among users, particularly since the consultation process has been strongly criticized. We question how fairly the effort required by the park's creation was distributed, particularly given the lack of information and limited legitimacy afforded to the consultation process. Finally, we look at the blaming that has taken place amongst different users of the park - a process compounded for many of those interviewed by their fear of being deprived (unjustifiably, they felt) of their freedom to access nature.

Keywords: sociology; French national park; environmental inequality; environmental effort; environmental justice. 
RESUMO: Na França, como em outras partes do mundo, políticas de proteção ao meio ambiente parecem ter notado a resistência local impulsionada pela expulsão de populações e restrições sobre o uso de determinadas áreas. A alteração na lei sobre parques nacionais franceses (Reforma de 2006) reconheceu que as populações locais podem ajudar a proteger ambientes naturais, bem como o seu direito de participar na definição da escritura (ou plano espacial) de novos parques. Este artigo analisa a criação e a aceitação local do Parque Nacional de Calanques, um parque periurbano e o primeiro de uma nova geração de parques na França continental. A nossa abordagem baseia-se no quadro analítico do esforço ambiental. Usando um corpus qualitativo de entrevistas semiestruturadas e observação direta, exploramos três eixos analíticos. Começamos por analisar o processo de consulta realizado durante a criação do parque. Isto aponta as desigualdades de acesso à esfera pública e ressalta que apenas algumas organizações de usuários dotadas de recursos realmente ajudaram a definir o "bom uso" de Calanques, o que se tornou uma referência na Escritura do parque. Em seguida, examinamos como tal participação desigual dos usuários impactou a redação da Escritura e a distribuição do esforço ambiental exigido de diferentes usuários. Por último, as duas primeiras observações levam-nos a questionar a aceitabilidade do esforço exigido e sua divisão entre os usuários, principalmente porque o processo de consulta tem sido fortemente criticado. Questionamos quão justamente distribuído foi o esforço exigido para a criação do parque, sobretudo tendo em conta a falta de informação e a legitimidade limitada conferida ao processo de consulta. Finalmente, olhamos para as acusações de culpa trocadas entre os diferentes usuários do parque, um processo agravado para muitos dos entrevistados pelo medo de serem privados (injustificadamente, eles sentiram) de sua liberdade de acesso à natureza.

Palavras-chave: sociologia; parque nacional francês; desigualdade ambiental; esforço ambiental; justiça ambiental.

\section{Introduction}

In France, the creation of national parks under the 1960 Parks Law has been the source of much conflict. Some of the country's parks remain mired in conflict, while the creation of other parks has been blocked altogether (Larrère, 2009). In an attempt to overcome the local resistance that inevitably accompanies having a natural site classified as a national park, the French government passed a new law in 2006 which grants greater power to local elected representatives, explicitly recognizes the rights and knowledge of local users, and invites them to participate in actually defining the park project. Our research into the creation of the new Calanques National Park, ${ }^{1}$ however, indicates that the application of these new principles actually tends to reinforce the environmental inequality that they were meant to reduce. How should we interpret this apparent paradox?

The goal of this paper is to outline the interactive processes that worked to strengthen local environmental inequalities during the creation of the Calanques National Park. To do so, we will use the analytical framework of environmental effort. Environmental effort may be defined as the socially differentiated and potentially unfair contribution of social actors to public environmental protection policies (Deldrève and Candau, 2014). We will begin by looking at both the weight of procedures and the more structural factors underpinning the inequality of access to the public sphere. We will

\footnotetext{
${ }^{1}$ CDE-Calanques: A new national park in the Calanques? French government CDE research programme, 2008-2011, V. Deldrève (Irstea) and P. Deboudt (Université de Lille 1) ed., FHUVEL: Human activities and vulnerability of coastal areas French government Liteau research programme, 2010-2013 (T. Tatoni ed., with C. Claeys). The analytical framework used to examine environmental inequalities and effort is that of the Effijie project (ANR Socenv, Candau and Deldrève, eds., 2014-2018): Environmental effort as inequality: Justice and iniquity in the name of the environment. For a comparative analysis of biodiversity and water policies in mainland France and its overseas departments.
} 
then show how the procedures adopted for dialogue tend to reproduce the asymmetry of the public sphere (in the Habermasian sense) that developed throughout the $20^{\text {th }}$ century around the protection of the Calanques. ${ }^{2}$ Next, we will examine who was actually involved in defining and distributing such effort; how this dialogue helped legitimize a "good use" of the Calanques and grant certain privileges; and how it reinforced certain types of inequality in access to the Calanques based on tradition and merit. National parks are one of the most restrictive tools for protecting nature and the effort they require is in large part translated into regulatory terms. In the last section, we will present a typology of points of view based on the users interviewed, regardless whether or not they were represented in the consultation phase. This typology will allow us to examine the criteria and principles that individuals use to deem fair or unfair the feared and/or expected bans and restrictions on use - i.e., the effort potentially required of users - inherent to national parks.

\section{Theoretical framework}

Why talk about environmental inequality or environmental effort as part of protecting the environment? Environmental inequalities have become of increasing interest to the field of public policy and research. This has been true since the 1980s and 1990s in the United States, under the impetus of the environmental justice movement, and in Europe since the 2000s through the register of sustainable development. Semantics (ecological vs. environmental) aside, these inequalities are defined in the broadest sense as inequalities in the relationship that populations and social groups have with their environment. They relate to the impact that such groups have on their environment via their production and consumption patterns. They are also connected to their exposure to risk, access to natural resources and amenities, ability to take environmental action and to benefit from policies in this field. Such inequalities are compoundable and bound up with other types of inequality (e.g., socio-economic and cultural); they are a facet of environmental justice that public policy cannot ignore (including for reasons of efficiency). So, concretely, who has to support the effort that such policies require of current generations to protect the environment? Economists differ in their findings on this topic. Some argue that it is the wealthiest who offset their higher impact by contributing more to protection measures via their resources (Lipietz, 1998); others claim that it is the poorest who contribute more despite the fact that their impact is lesser, as is the benefit they draw from it (Pye et al., 2008; Martinez-Alier, 2008). Local protests over French national park policy (Larrère, 2009) and its 2006 reform encourage us to look more closely at this controversial debate. The Calanques National Park - which is a product of the 2006 reform and is located on the doorstep of an agglomeration of two million inhabitants - is a particularly salient example since it touches directly on the effort required of locals and users of the Calanques.

We will argue that "environmental effort" is the source of much inequality. In practical terms, this concept refers to all positive and passive actions (e.g. non-consumption of a given resource) carried out to preserve natural resources and amenities. In terms of protected areas, environmental effort may come in the form of rules and regulations via ac-

${ }^{2}$ The Calanques are a group of rocky coastal inlets located near the city of Marseille, in southern France. 
cess rights or the stipulation of which activities are authorized within a given zone. It can also involve restrictions to access. Restrictions are not always physical, however, since they may also be based on the value attached to relevant local amenities (natural beauty or the possibility for recreational activities, for example). Moreover, such value may differ depending on social category and type of use - and it is also dependent on cultural norms, which may place greater value on one type of use over another (Deldrève and Candau, 2014).

It is therefore necessary to ask who defines what are "good uses" of nature and a fortiori of protected areas. We posit that inequalities in effort are directly connected to inequalities in participation as a peer in social life, in the sense defined by Nancy Fraser (1990). The misrepresentation (Fraser, 2005) $)^{3}$ generated by consultation procedures therefore helps reinforce environmental inequalities since certain groups are not able to defend their vision and uses of the environment in the public policy sphere. More broadly, inequalities in participation are connected to structural inequalities - both socio-economic and cultural - which also result in unequal access to the "public sphere" in the Habermasian sense $e^{4}$ or, to paraphrase Iris Marion Young (1990) and Nancy Fraser (1990), in a nonrecognition of the diversity of publics.

\section{Methodology}

We have been conducting sociological research into the Calanques National Park since 2008.
This began in the context of two research programmes, one focused on the consultation process surrounding the creation of the park (Deldrève and Deboudt, 2012) and the other interested in land- and sea-based uses of the territory of the future park (Tatoni et al., 2013) (Figure 1).

This paper is based on a corpus that combines data collected during direct observation and from a qualitative survey (using semi-structured interviews). Between 2008 and 2012, we observed thirty-two dialogue meetings and conducted two hundred and thirty interviews with managers, experts, actors from the non-profit sector, and participating and non-participating users of the Calanques and surrounding islands. Among the users interviewed who did not participate in the consultation process, 125 were met directly onsite, primarily in one land-based area and three sea-based locations. The chosen land area - the Marseilleveyre massif between the Mont-Rose and Marseilleveyre Calanques - is one of the entry points into the Calanques closest to Marseille. The first sea-based location is a popular diving spot called Les Farillons, within the Riou archipelago. The second is Sormiou Bay, the largest natural anchorage area in the Calanques, famous among yachters; the third location is a natural anchorage zone in the Frioul archipelago particularly near the main town harbours. We recorded the interviews and meetings, and all interviews were transcribed. We then thematically analysed this data-set manually and using nVivo $\odot$ software.

\footnotetext{
3 Nancy Fraser argues that there are two such types of injustice. The first is "ordinary" and arises when populations are denied the opportunity to participate as peers in decisions that affect them, despite being recognized as members of the "political community". The second is more obscure and covert; it is the effect of a misframing which excludes from the decision-making community populations that "should" participate and are as such made invisible.

4 Let us recall that, for Jürgen Habermas (1997 [1962]), the public sphere is a freely accessible space for rational debate and permanent, public deliberation. It is independent from public authorities, guided by the principle of publicity and as such equipped with critical power, a power of communication capable of opposing the more administrative power the State.
} 


\section{Périmètres du Parc national des Calanques}
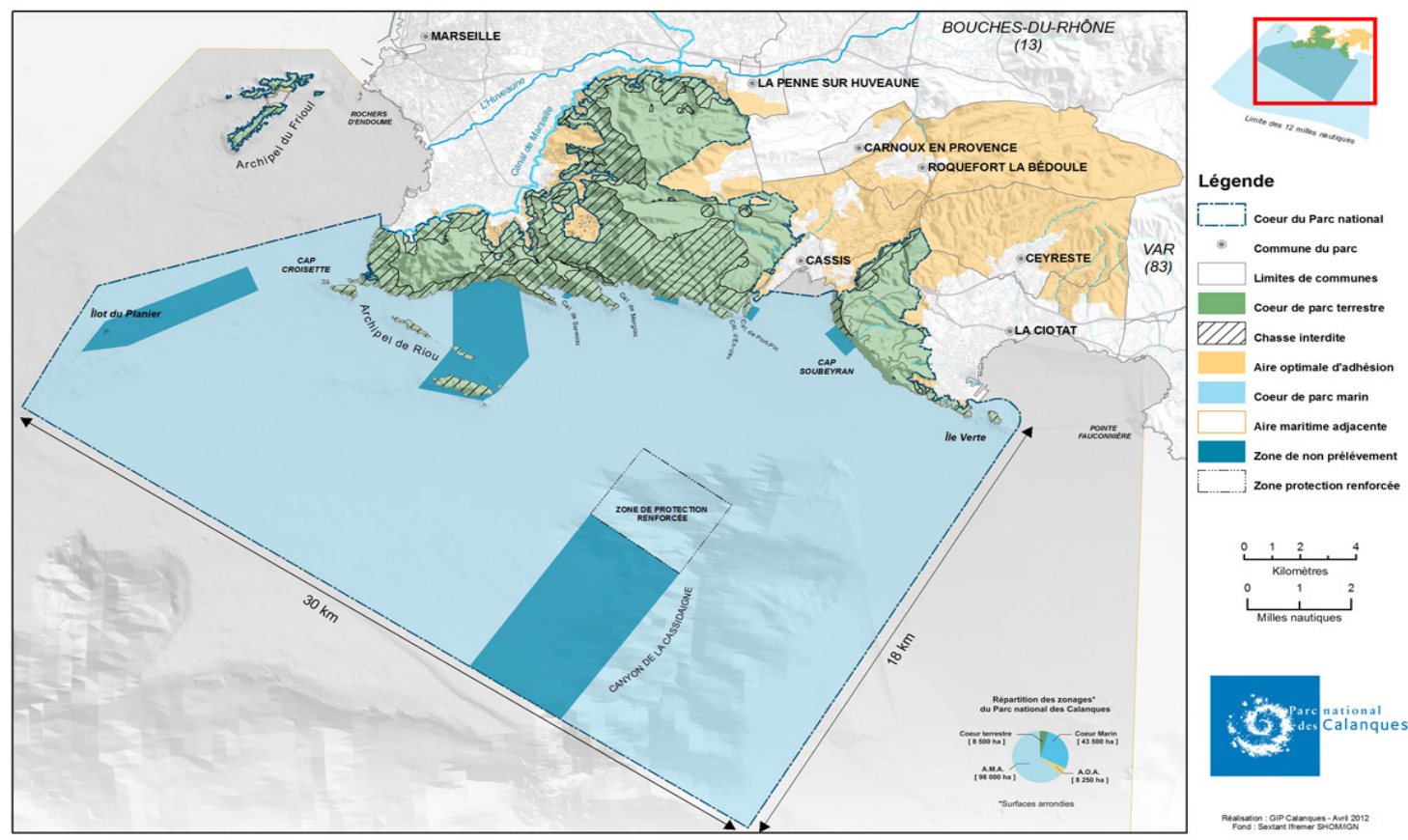

FIGURE 1 - The Calanques National Park (www.calanques-parcnational.fr/fr/mediatheque/cartotheque).

\section{Unequal access to the public sphere: who defines environmental effort?}

Since the turn of the last century, the Calanques have been the focus of a great deal of protest by recreational groups (e.g. hikers, climbers, followed later by local hut owners and renters). Like in other parts of the world, such upper- and middle-class groups have banded together to oppose urbanization and industrial activity that pose a threat to the natural environment. Such groups were key to having the Calanques classified as a natural heritage site in 1973. They were also instrumental in the eventual creation of a national park, and some of them were board members of the Public Interest Group ("GIP") 5 formed in 1999 to manage the Calanques' transition to National Park status.

Part of the process of creating a national park required a dialogue with local stakeholders, the goal of which was to collectively establish a charter - i.e., a territorial roadmap for the park. ${ }^{6}$ There were two guiding principles to how the

${ }^{5}$ A GIP brings together legal entities governed by both public law, such as the government and local municipalities from the area, and private law (individuals). The general assembly of the Calanques' GIP (40 members) and its board of directors ( 24 members) is as such comprised of three colleges: the government and state-owned enterprises; local municipalities; and "civil society", i.e. the non-profit sector and private owners.

${ }^{6}$ The consultation process lasted a year and was divided into five thematic workshops: "land uses", "water uses", "organizing the management of the core area", "understanding the heritage and character", and "ecological solidarity or the ideal peripheral area". Territorial workshops were also conducted alongside the above in the form of public meetings and private fora for elected officials. Finally, there were also several bilateral 
consultation stage was constructed. The first, a reference to the Grenelle de l'Environnement (French political meetings in 2007 that resulted in environmental commitments), required having the five types of civil society actors represented (elected officials; government representatives; professionals; inhabitant-, user- and environmental protection associations; and researchers and technical experts). The GIP managerial team and its director (a senior government official) further identified an overarching category - comprised of owners, and private and especially public managers of the Calanques $^{7}$-which was defined as having "priority" in the consultation process and with whom it communicated regularly during meetings prior to the consultation workshops. The second principle required the representation of a majority of users and activities from the sites. In keeping with these procedural norms, members of the GIP managerial team specifically identified groups of people who appeared most organized and legitimate.

As a result, the aforementioned recreational users of the Calanques - who are both active and resourceful - were essentially first in line. When the National Park was created, there were no recent data on the types of people that visit the Calanques. Thus, the wide variety of social backgrounds of such visitors and the diverse activities they take part in were not identified as part of the dialogue process. Further, no effort was made to redress the imbalance caused by the overwhelming presence of certain users in this process. This same group, whose leaders belonged to both user and resident organizations, did not shy away from exerting their influence. They did not hesitate to go "over the heads" of the GIP and contact local and national elected officials (and even the media) when they felt that their views were not given sufficient consideration by scientific and technical representatives.

Eventually, an agreement was struck between these users and the GIP team, whose job was to apply IUCN and French government philosophy and ecological specifications pertaining to national parks. Despite a series of controversies (e.g. over the impact of different practices), an "apparent consensus" (Urfalino, 2007) was reached and the practices of these recreational stakeholders were recognized as environmentally-friendly, "traditional" and "worthy" (Deldrève and Deboudt, 2012). Such practices were reframed through the lens of an ecological imperative: "We were the trailblazers of sustainable development", "our practices are ecocompatible" (hut owners' representative); and their impact - questioned by researchers - was described as minimal and responsible: "We fish responsibly, we know what we're doing, we do not stress the ecosystem so as not to disrupt it" (fisher, small leisure boat). The term "traditional" was never precisely defined and was taken to mean "longstanding, and passed down through generations": "Going down to the hut is a tradition - my tradition, and it comes from my grandparents. I spent all my holidays here as a child. Everyone knew each other. Now I come down with my grandchildren and the tradition lives on" (hut owner in Sormiou). However, research has shown that local power

meetings (e.g., the hunting group, climbing group, etc.). In all, this represented roughly 150 meetings and 500 hours of debate, in addition to the drop-in office hours which were not particularly well attended.

7 This included the Office National des Forêts (National Forest Office), Marseille town council, Conservatoire du Littoral (coastal protection agency), Bouches du Rhône General Council, Cassis town council, Ministry of Defence, Electricité de France and private owners who had created an association since 2000 . 
dynamics also work to shape who is recognized as indigenous and which practices are liable to be classified as "traditional" (Retière, 2003). In the case of the Calanques, some long-standing but littlevalued practices were not considered "traditional" despite the fact that they had been passed down for generations. During the dialogue process, many uses of the park were criticized without taking into account the modern technological developments tied to other "traditional" activities. The activities given the most merit were those involving physical exertion, such as walking and climbing (Figure 2), those that involved "roughing it", like staying in a hut with no electricity or running water, and those that required specialized knowledge of the local area, such as hunting (Figure 3), gathering food and fishing.

The attribution of merit to some activities occurred at the expense of other, less demanding activities, like tourist boating (Figure 4), picnicking and sunbathing. The allegedly "good uses" (Massena-Gourc, 1994) of the park had a relationship with nature that was primarily ascetic and contemplative (Figure 5) (Fabiani, 2001). The fact that this category was comprised almost exclusively of activities enjoyed by individuals of middle and

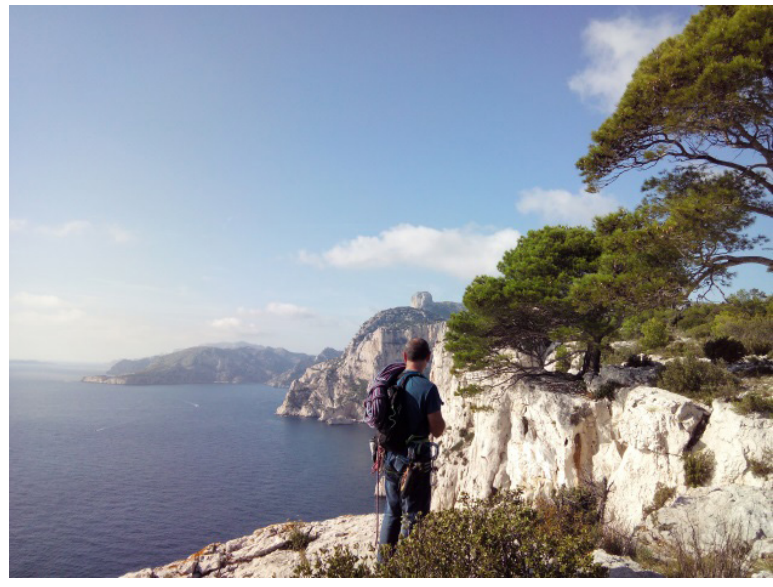

FIGURE 2 - Rock climbing (Claeys, 2015).

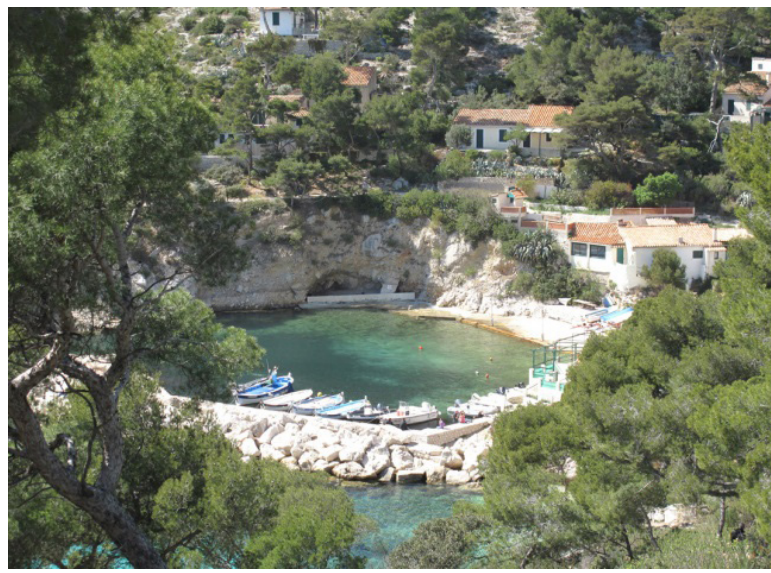

FIGURE 3 - Sormiou huts (Cresp, 2012).

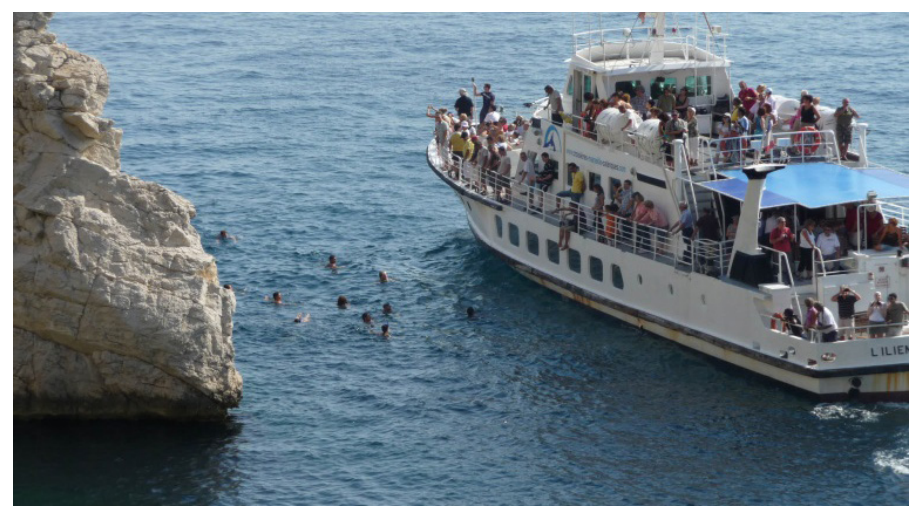

FIGURE 4 - Tourist boating and swimmers (Cresp, 20120).

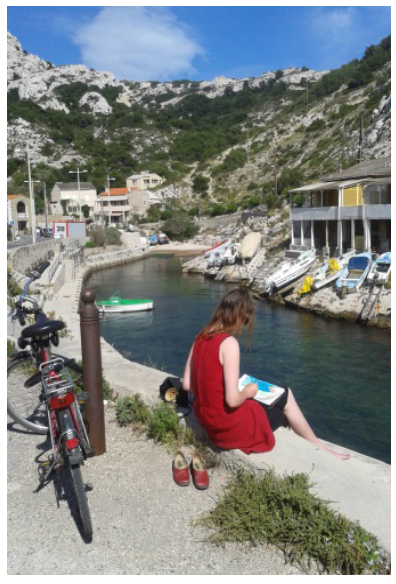

FIGURE 5 - An amateur painter (Claeys, 2015) 
upper socio-economic status worked to create social inequality and further drove environmental inequality through the attribution of merit to certain activities in public policy.

\section{Unequal access to the Calanques: who should shoulder the environmental effort?}

When the charter for the Calanques National Park was drawn up, the three-faceted recognition enjoyed by some groups (as ecological, traditional and "worthy") meant that they were able to more easily defend the privileged status they had attained during the dialogue process. For example, the charter forbids fires within the park - with the exception of barbecues at people's huts. All dogs are to be kept on a lead - except those used for hunting. Initially, "traditional" fishing competitions were allowed, but spearfishing competitions were not. ${ }^{8}$ Moreover, the road leading to the Sormiou Calanque (closed in summer to limit the risk of fire and regulate access to the Calanque and maritime public property) remained under the authority of the mayor ${ }^{9}$ and, according to our observations, the hut renters' association and its manager, who have the final say over who is granted access.

The lack of voices defending alternative uses of the national park contributed to such uses losing credibility. The users involved in these other activities tended to be young or low income local residents, as well as tourists. Their activities were deemed the cause of "excessive amounts of visitors" or labelled "environmentally harmful and antisocial". While perception alone could not stop these groups from accessing the park, their activities were viewed as a nuisance that needed to be controlled and contained. And as a result of such perception, greater environmental effort was required of the members of these less privileged groups. Our research, as well as that conducted by researchers in the fields of environmental justice (Taylor, 2000; Evans, 2008) and political ecology (Peluso, 2012) point up that such problems are never purely environmental. One example of a particular group being subject to this kind of criticism is the case of the young, low-income residents who live near the Sormiou Calanque. These residents congregate in the area to socialize and partake in leisure activities, much to the displeasure of local hut renters: "The kids go directly to the beach, that's all they've got $[\ldots]$ they walk there or hitchhike [...] like I used to, also. I did that and so I taught my kids to do the same and so that's what they do" (resident of La Cayolle); "[...] Now, if I want to hang with all my buddies, I go to Sormiou" (young inhabitant of $\mathrm{La}$ Cayolle, forester).

There have been complaints about arguments and public disorder, sometimes escalating into physical violence: "I called the police. They come down here, they damage everything, insult you. And if you say anything, they set things on fire" (hut owner in Sormiou). The council where these people live has long suffered from a bad reputation in the public eye and is reputed to be an unsafe place to visit: "It's Chicago [...]. You can't let tourists go there, they'll get robbed" (resident from a neighbouring district). At the same time, the environmental value of the district - historically

\footnotetext{
8 The ban on competitions was later extended to include all categories in the final version of the park's charter.

9 According to the 2006 law on parks and following an amendment proposed by Jean-Claude Gaudin (the current mayor of Marseille) pertaining to municipalities of over 500000 inhabitants, the municipality retains its authority to police matters related to the management of roads within the park's core area.
} 
designed as a place of social relegation successively populated by waves of immigrants - has increased over time, first as a result of its proximity to the Calanques, and then with the pending creation of a national park. Because of this, it is becoming more and more attractive to property developers and people of wealthier social standing (Hérat, 2012). This process seems to be pushing the most economically distressed populations out of the district, i.e. farther from the natural amenities that originally formed the backdrop for their living conditions and leisure activities: "My father would say, 'come on, get ready, we're going to the hill...let's go take a little walk'. [...] Now they [her children] go to Sormiou because Sormiou's their spot" (resident of La Cayolle).

The 2006 French National Park Law calls for the rights and knowledge of local users to be recognized. Its application in the case of the Calanques National Park, however, was based on local power relationships and dominant norms regarding "good uses" that determined which local users were able to benefit from such recognition (Ginelli et al., 2014). These norms were apparently consensual during the dialogue process, as they were more broadly in the public sphere, including within the protest movement against the creation of the national park. This movement was driven by a group composed of professional stakeholders who felt they were not sufficiently consulted (such as aquatic sports professionals) who were quickly joined by "traditional" recreational users who dissociated themselves more or less sustainably from the GIP (e.g., climbers opposed to the initial plan for a strict nature reserve; the majority of hut owners and renters; and hunters). Such protest came therefore not from a "weak public" or a "counterpublic" in the sense coined by Nancy Fraser; rather, it was conducted under the same banner as those participating in the consultation process and users who supported the park - i.e., it advocated respect for worthy, local habits and customs. ${ }^{10}$ But, while partisans of the park's creation felt that the park and the authority of its director (appointed by the government) would ensure the protection of the Calanques and their traditions (notably against the incessant push of urbanization projects), its opponents feared that the director would overshadow the authority of local representatives and place "in the hands of a senior government official" the future of their traditional practices, already threatened by the tourist appeal of the national park label.

And yet beyond the visible public sphere itself, discord over the park's creation was based less on the image of the park and the role of the government than on the regulation that inherently comes with a national park.

\section{Acceptance/unacceptance of environmental effort and feelings of injustice}

The rules and regulations inherent to the creation of the Calanques National Park can be interpreted as a legal and potentially coercive formalization of the definition of a "good use" of nature and of its implications in terms of distributing environmental effort. The stricter regulations that would come with the Park's creation were of great

\footnotetext{
10 As an example, the goal set by the collective that served as an umbrella group for opposition to the park's creation was to "Protect the practice of cultural, professional, sporting and leisure activities while respecting nature and our traditions within the Calanques massif, harbour of Marseille and along the coast, both on land and at sea" (source: http://www.amisradecalanques.fr/?page_id=58).
} 
concern to all users, both those who participated and non-participants in the consultation process. The different arguments advanced do not fit neatly into simple categories of "for" or "against" the regulations, however. They can be categorized into five ideal-types.

In support of more regulation: From this perspective, greater regulation surrounding access to the Calanques and its archipelagos in the context of the national park's creation was desired or at least seen as inevitable. There were two levels of support for this position, which need to be further broken down.

\section{- A (vindictive) request for greater regula-} tion: Such calls for greater regulation were mainly aimed at other users, thus pointing up the existence of conflicts of use (Claeys et al., 2011); all types of users could be accused or the accuser. For example, professional and amateur fishermen blamed each other for destroying fish resources; divers and recreational boaters mutually accused each other of damaging the sea bed with their moorings, while together they condemned jet-ski users who seemed to embody "bad use" given the noise pollution and excessive speed of their activity: "It's dangerous because you don't need a real licence. People think they're on a circuit but there are people out there swimming, spearfishing and freediving, etc. It's totally nuts, and very dangerous - and not sufficiently regulated" (a recreational boater). "In a national park, a sport that disrupts nature and all other users should not be allowed..." (a swimmer and walker).

- (Resigned) acceptance of increased regulation: Here, the increased regulation that comes with the creation of a national park was seen as inevitable and people as such felt they would need to resignedly adapt their practices. It was as such that this recreational boater mentioned the predictable restrictions to anchoring in open roadstead:
"Outer mooring damages the sea bed. So it's going to be forbidden one of these days. It's absolutely inevitable [...] to accept such constraints if we want to still be able to enjoy this in twenty or thirty years". Similarly, this amateur gatherer-collector acknowledged that, "Everyone needs to make an effort. We don't have a choice if we want to keep our Calanques. Sure, the park is a pain if we can't pick and gather or go where we like... But if we want to keep all this, we can say that, despite the constraints, it's a lesser evil."

A rejection of greater regulation: Opposition to increased regulation was also based on two more or less radical positions.

- Existing regulation deemed sufficient: From this perspective, regulation per se was not the issue, but the existing regulations were deemed sufficient. This view tended to be accompanied by remarks underscoring that it would suffice to correctly enforce the existing legislation rather than create more rules. A hut owner as such noted, "It's a conservation area. It was created years ago. So why go and add another layer and more constraints now?" A walker and recreational boater also mentioned an economic argument: "Particularly since there are already laws in place and they are not enforced. So what is the point of creating others? What's the point of creating a park that's going to cost hundreds of millions of euros a year when everything already exists? Why not just enforce what already exists?"

\section{- A rejection of the principle of regulation:}

This opposition to regulation was directly tied to a refusal to let go of one's own use of the Calanques and its archipelagos. Users defended the environmentally-friendly nature of their activities in the Calanques. They underscored their concern for the site's conservation and deemed it more efficient than any coercive regulatory tool could be. This position included forms of protest against 
public authorities as well as against researchers and scientific experts. One recreational boater as such criticized the connivance between decision-makers and researchers: "When these people become honest... I'm talking mostly about the politicians and maybe also the researchers who don't want to upset the politicians because it could lead to less money for them." Such opposition also took the form of identity-based claims: "We are the guardians of the Calanques," said one local; "We are the sentinels of the sea" said a fisherman. As such, they felt they should remain the sole trustees of "good use" and its prescription. "We go see the tourists and we tell them not to leave their garbage lying around, or to be careful - some go off wearing sandals, without any water or a map. We also help prevent the risk of fires. And now they want to teach us lessons like children. But we didn't wait for the park" (hut owner, hunter).

For an educational and incentive-based alternative: This position was a compromise between the acceptance and refusal of regulation. It advocated for a sort of third way based on information, awareness-raising and education amongst users. This walker weighed prevention and repression: "So, yes, work to prevent rather than repress." Another reasoned in terms of education: "But you need to educate people about respecting the site..." One diver suggested, "that we not head in the direction of more restrictions and regulations. I think it is more important to inform, to communicate [...] sincerely. If we explain things a bit, the reasoning behind things, everyone is capable of understanding, especially us, those involved with the coastal life of the Bay of Marseille. It's our work, so we all have an interest in protecting it." Awareness-raising should as such be the first goal of the park: "If the park bans something but no one explains why, it won't work. People will always find a way to do it..." (a walker, educator).

While the position of those interviewed towards regulation was certainly influenced by their use and profile, it can by no means be reduced to such variables alone. The diversity of points of view was visible both amongst users described as "traditional" during the consultation process and amongst other users. The acceptance of effort was rooted not only in people's relationship with the natural environment, but also in their relationship with others. Much of the discourse was tinged with distinctions between "good" and "bad" users and the refusal to partake in the shared effort was in large part based on the belief that this distinction was unfair. In conducting interviews, two types of feelings of injustice emerged. The first set was related to the conditions in which effort was defined and who had to support it - and it was directly tied to criticism about the consultation process. The second set pertained more directly to the way this effort was distributed and to the related sense of inequality therein. Feelings of injustice were at times reinforced by a sense of lost legitimacy and even of dispossession.

During the interviews, users were asked about their awareness of the on-going consultation process over the national park project. Overall, awareness of the consultation process was quite limited. Of the users met in the field that were aware of the consultation process, most were critical of it. Their criticism hinged on 3 main points: 1. The unrepresentative nature of the population invited to take part in the consultation meetings, deemed too restrictive and not representative of the whole community: "I believe that hut owners are consulted, but, personally, I've never seen anyone doing surveys in the street or..." (a walker); "No one ever consulted us about anything at all, there 
are CIQs (citizen committees), I think, but they're limited..." (an inhabitant of a local neighbourhood in the Calanques). 2. The fact that some stakeholders could speak louder than others and were heard at the expense of other user groups: "The hunters want to hunt, the fishers want to fish, the walkers want to walk, everybody [...], because you always see the same people in these discussions, it's odd, isn't it? You always see the same faces, be it the politicians or the others there, you see their photos in the paper and they're in the discussions but, in the end, nothing ever moves forward" (a walker). 3. The "divisive alliance" between policy-makers and GIP scientific advisers, who had allegedly decided everything in advance: "I attended two things and it was a non-consultation process. It was... They convened people to say the public was consulted, but the project was already finalized and... Afterwards, there was a general uproar, so they pretended to convene all the different players, but everything was already decided, so... In my opinion, they gave a little bit, some food for thought, and they backtracked on two or three things" (a recreational boater).

Many of the users we met were particularly reticent about accepting the environmental effort required by the creation of the Calanques National Park since they felt their impact on the environment was insignificant compared to the impact of other sources of disruption and pollution. While there was disagreement between them over whether it was underwater hunters, recreational fishermen or professional traditional fisherman who depleted more fish stocks, or whether it was the climbers or walkers who caused more damage to the fauna and flora, everyone agreed that their respective impact needed to be put into perspective compared to the waste from the treatment plant for the city of Marseille that is dumped into the Cortiou Calanque or the industrial red mud that flows into the Bay of Cassis. The most vindictive comments came from sea users involved in leisure boating, scuba diving and fishing: "Based on that, I find it completely abnormal that there is waste like that and then they go and make a natural park, you see. You get the impression that they're passing the buck to others, you know, to the people" (couple of recreational boaters). Some recreational fishermen expressed their dismay: "We're just out to catch a couple of fish, we will never deplete the sea, I promise you [...]. They're going to ban it on us and that's enough... You'll see, things are going to get tough then."

Users felt that it was environmentally pointless and unfair to force them to pollute- or fish less when there were factories that dumped their sludge directly into the water of the future park, and industrial fishing boats trawling off-shore. Some users as such questioned the relevance of a park given the economic interests and asymmetrical relationships: "What's the point of a park if there's no way to stand up to the big guys? It's always the little guys who get hit" (traditional fisherman). Making an effort in this context was seen as bearing responsibility for the damage done by others.

Lastly, this sense of injustice tended to be exacerbated in the case of a peri-urban national park given the spatial proximity between the city and the protected area (Figure 6), as well as due to the multiple and even ambiguous status of this nature for urban users who viewed it as either - or at once both - remarkable and ordinary (Figure 6), wild and domestic (Claeys et al., 2012).

In other words, it is particularly frustrating to have to change the way you use a place when it is nearby and familiar. The issue hinged on both the sense of injustice over who was responsible for environmental problems, and on the sense that an indigenous relationship with nature - one that was 


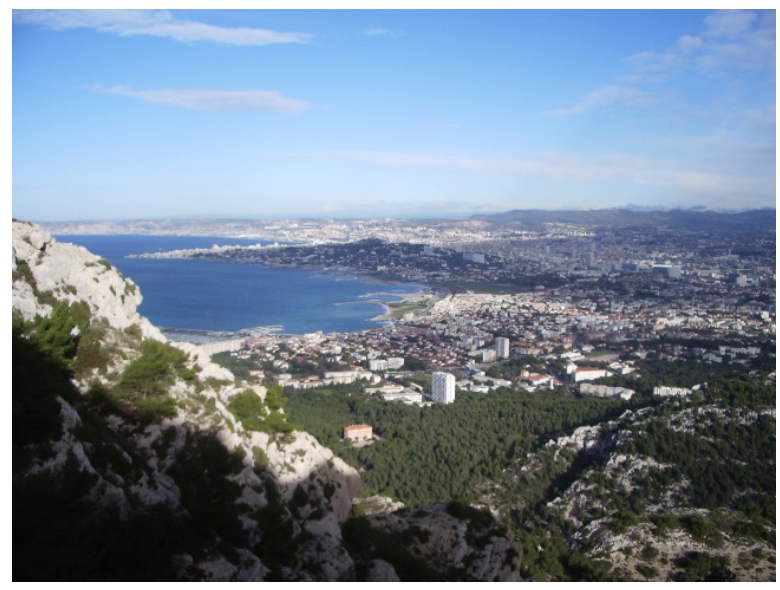

FIGURE 6 - Marseille from the National Park (Cresp, 2012).

special and experienced as "free" - was being challenged for reasons that remained incomprehensible or unacceptable. "The Calanques are our garden and we have taken care of them. We have always been able to pick things and fish... Now they're going to tell us to stop or to stay on the paths. Do you find that fair?" (a local, hunter's wife); “They're going to treat us like Indians and make a park for the tourists" (hut owner). Without addressing the issue of who owns the land, the views collected during the interviews point up several types of appropriation: "It's our Calanque [it belongs to us, hut owners]"; "It's the garden of Marseille's inhabitants" (Figure 6); " (...) The people need their Calanques, because it's their Calanques... It's freedom... You see, it's their oxygen... Freedom of movement..."; "The Calanques belong to everyone."

Equality and freedom of access for all or only for the inhabitants of Marseille were mentioned but not retained as principles of justice during the consultation process, in which the definition of good use and the distribution of effort were mainly conceived, as we saw above, through the lens of tradition and merit.

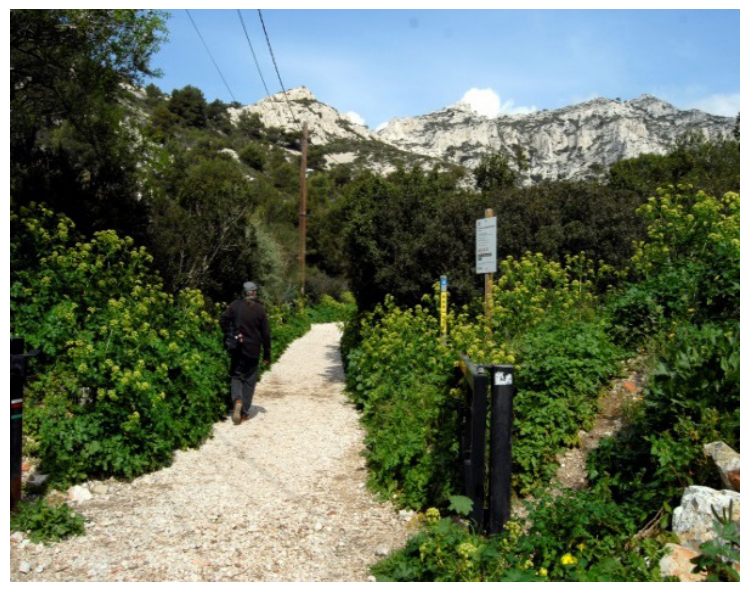

FIGURE 7 - An entrance into the national park (Deldrève, 2015).

\section{Conclusion}

The 2006 reform to park policy embraced a more procedural approach (Lascoumes et al., 1998) and as such strengthened the power of actors from the public sphere - and, in this sense, it fostered democratic change. But it also reinforced a vision of democracy that was limited to "strong publics" (Fraser, 1990), users who were defending a natural site while simultaneously protecting their use of it. Whether this result is common to all "new generation" national parks or those affected by the 2006 reform remains to be proven. Our findings nonetheless echo research conducted into the history of nature protection around the world, shown to be strongly influenced by recreationist elites and their vision of the world (e.g., Cronon, 1996; Benjaminsen and Svarstad, 2012; Selmi, 2009). In this sense, the result of the 2006 reform is more part of a continuum than an actual break with the past.

The 2006 reform also implicitly helped bolster environmental inequalities since it institutionalized a definition of "good use" that complied with the norms of certain groups. Environmental norms are 
not always legal in nature. They are invisible, most often a tacit part of behaviour and help shape access to natural sites (Evans, 2008). But in a national park, they also have a regulatory dimension since it is necessary to distribute environmental effort.

If, more than personal interest alone, it is the principles used to justify the effort required that broadly condition its acceptance, then the challenge to come for the park will be to broaden the discursive sphere in order to re-open debate over what is fair. There is of course a risk to broadened dialogue since it will re-open debate in areas where consensus was hard to reach. But such consensus

\section{References}

Benjaminsen T.A. ; Svarstad H. Discours et pratiques de conservation en Afrique. In: Gautier, D.; Benjaminsen, T. A. (Eds.). Environnement, discours et pouvoir. L'approche Political Ecology. Versailles: Quae, 2012. p. 111-134.

Claeys, C.; Barthélémy, C.; Tatoni, T.; Bonhomme P. Protected Areas and Overuse in the Context of Socio-Natural Changes: An Interdisciplinary French Case Study. International Review of Social Research, 1(3), 73-92, 2011.

Claeys, C.; Gonsales J. N.; Barthélémy C. Marseille et ses natures: perméabilités spatiales, segmentations sociales. Desenvolvimento e Meio Ambiente, 26, 69-85, jul./dez. 2012.

Cronon, W. The trouble with wilderness: or, getting back to the wrong nature. Environmental History, 7-28, 1996.

Deldrève, V.; Deboudt, P. (Eds.). Le Parc National des Calanques. Construction territoriale, concertation et usages. Versailles: Quae, 2012.

Deldrève, V.; Candau J. Produire des inégalités environnementales justes... ou injustes. Sociologie, $<\mathrm{http} / / / \mathrm{www}$. cairn.info/resume.php?ID_ARTICLE=SOCIO_053_0255>, 2014.

Evans M.-M. La "Nature" et la justice environnementale. Ecologie et Politique, Presses de Sciences Po, 1(35), 3345, 2008. was built on the exclusion of groups (Rancière, 1995) who are also asked to bear the burden of effort. Raising awareness about the topic of protection - a "priority" for some users and on the national park's agenda - might help encourage consent from those groups least familiar with these issues. That will not suffice, however, because people's relationship with regulation cannot be reduced to a question of awareness-raising alone. Rather, it touches on equity, both in terms of the distribution of effort and in terms of helping to define it. In this sense, the park cannot afford to shy away from the question of environmental justice.

Hérat, A. Une politique de nature à l'épreuve du territoire: le quartier de la Cayolle et la calanque de Sormiou (Marseille). In: Deldrève, V.; Deboudt, A. (Eds.). Le Parc National des Calanques. Construction territoriale, concertation et usages. Versailles: Quae, 2012. p. 53-72.

Fabiani J.-L. L'amour de la nature. In: Boyer, M.; Herzlich, G. et al. (Eds.). L'environnement, question sociale. Paris: Editions Odile Jacob, 2001. p. 39-48.

Fraser, N. Rethinking the Public Sphere: A Contribution to the Critique of Actually Existing Democracy, Social Text, Duke University Press, 25-26, 56-80, 1990. URL: <http:// www.jstor.org/stable/466240>.

Fraser, N. Reframing global justice. New Left Review, 36, 69, 2005.

Ginelli, L.; Marquet, V.; Deldrève, V. Bien pratiquer la nature... pour protéger les Calanques? Ethnologie Française, 44(3), 525-536, 2014.

Habermas, J. L'espace public. Archéologie de la publicité comme dimension constitutive de la société bourgeoise. Paris: Payot, 1997 [1962].

Larrère, R. Histoire(s) et mémoires des parcs nationaux. In: Larrère, R.; Lizet, B.; Berlan-Darqué, M. (Eds.). Histoire des parcs nationaux : comment prendre soin de la nature? Paris: Quae, 2009. p. 23-42. 
Lascoumes, P.; Le Bourhis, J.-P. Le bien commun comme construit territorial, identités d'action et procédures. Politix, 42, 37-66, 1998.

Lipietz, A. Économie politique des écotaxes. Rapport au Conseil d'Analyse économique du Premier ministre. Paris: La Documentation Française, 1998.

Masséna-Gourc, G. La protection à l'épreuve de la diversité des usages. Le massif des Calanques. Etudes Rurales, 133134, 149-162, 1994.

Peluso, N. Situer les political ecologies: l'exemple du caoutchouc. In: Gautier, D.; Benjaminsen, T. A. (Eds.). Environnement, discours et pouvoir. L'approche Political Ecology. Versailles: Quae, 2012. p. 37-64.

Pye, S.; Skinner, I.; Meyer-Ohlendorf, N.; Leipprand, A.; Lucas, K.; Salmons, R. Addressing the social dimensions of environmental policy: A study on the linkages between environmental and social sustainability in Europe. Bruxelles: European Commission, 2008.
Rancière, J. La mésentente. Paris: Galilée, 1995.

Retière, J-N. Autour de l'autochtonie. Réflexions sur la notion de capital social populaire. Politix, 16(63), 121143, 2003.

Selmi, A. L'émergence de l'idée de parc national en France. De la protection des paysages à l'expérimentation coloniale. In: Larrère, R.; Lizet, B. et al. (Eds.). Histoire des parcs nationaux. Comment prendre soin de la nature? Paris: Quae, 2009. p. 43-58.

Taylor, D. E. The Rise of Environmental Justice Paradigm. Injustice framing and the Social Construction of Environmental Discourses. American Behavioral Scientist, 43, 508-580, 2000.

Urfalino, $\mathrm{Ph}$. La décision par consensus apparent. Nature et propriétés. Revue Européenne des Sciences Sociales, XLV(136), 47-70, 2007.

Young, I-M. Justice and the Politics of Difference. New Jersey: Princeton University Press, 1990. 